\title{
The natural oscillations in stratospheric ozone observed by the GROMOS microwave radiometer at the NDACC station Bern
}

\author{
Lorena Moreira $^{1}$, Klemens Hocke ${ }^{1}$, Francisco Navas-Guzmán ${ }^{1}$, Ellen Eckert ${ }^{2}$, Thomas von Clarmann $^{2}$, and \\ Niklaus Kämpfer ${ }^{1}$ \\ ${ }^{1}$ Institute of Applied Physics and Oeschger Centre for Climate Change Research, University of Bern, Bern, Switzerland \\ ${ }^{2}$ Karlsruhe Institute of Technology, Institute for Meteorology and Climate Research, Karlsruhe, Germany \\ Correspondence to: Lorena Moreira (lorena.moreira@iap.unibe.ch)
}

Received: 22 January 2016 - Published in Atmos. Chem. Phys. Discuss.: 15 March 2016

Revised: 23 May 2016 - Accepted: 30 July 2016 - Published: 19 August 2016

\begin{abstract}
A multilinear parametric regression analysis was performed to assess the seasonal and interannual variations of stratospheric ozone profiles from the GROMOS (GROund-based Millimeter-wave Ozone Spectrometer) microwave radiometer at Bern, Switzerland $\left(46.95^{\circ} \mathrm{N}, 7.44^{\circ} \mathrm{E}\right.$; $577 \mathrm{~m})$. GROMOS takes part in the Network for the Detection of Atmospheric Composition Change (NDACC). The study covers the stratosphere from 50 to $0.5 \mathrm{hPa}$ (from 21 to $53 \mathrm{~km}$ ) and extends over the period from January 1997 to January 2015 . The natural variability was fitted during the regression analysis through the annual and semi-annual oscillations (AO, SAO), the quasi-biennial oscillation (QBO), the El Niño-Southern Oscillation (ENSO) and the solar activity cycle. Seasonal ozone variations mainly appear as an annual cycle in the middle and upper stratosphere and a semiannual cycle in the upper stratosphere. Regarding the interannual variations, they are primarily present in the lower and middle stratosphere. In the lower and middle stratosphere, ozone variations are controlled predominantly by transport processes, due to the long lifetime of ozone, whereas in the upper stratosphere its lifetime is relatively short and ozone is controlled mainly by photochemistry. The present study shows agreement in the observed naturally induced ozone signatures with other studies. Further, we present an overview of the possible causes of the effects observed in stratospheric ozone due to natural oscillations at a northern midlatitude station. For instance regarding the SAO, we find that polar winter stratopause warmings contribute to the strength of this oscillation since these temperature enhancements lead to a reduction in upper stratospheric ozone. We have detected a strong peak amplitude of about $5 \%$ for the
\end{abstract}

solar cycle in lower stratospheric ozone for our 1.5 cycles of solar activity. Though the 11-year ozone oscillation above Bern is in phase with the solar cycle, we suppose that the strong amplitude is partly due to meteorological disturbances and associated ozone anomalies in the Northern Hemisphere. Further, our observational study gave the result that ozone above Bern is anti-correlated with the ENSO phenomenon in the lower stratosphere and correlated in the middle stratosphere.

\section{Introduction}

There is a wealth of possible sources of natural variability in stratospheric ozone. The concentration of stratospheric ozone varies as a result of different factors, some interacting among themselves through their effects on chemistry and transport. The seasonal variations, given in terms of annual and semi-annual oscillations ( $\mathrm{AO}, \mathrm{SAO})$, have been studied for many years (e.g. Ern et al., 2015; Schneider et al., 2005; Cordero and Kawa, 2001; Garcia et al., 1997; Ray et al., 1994; Perliski et al., 1989; Delisi and Dunkerton, 1988; Maeda, 1984). On interannual timescales dynamical feedbacks in the Earth system lead to effects of originally tropical phenomena, such as quasi-biennial oscillation (QBO) and El Niño-Southern Oscillation (ENSO), on midlatitude wave structures and wave propagation. Planetary waves play an essential role in driving the zonal mean transport by the Brewer-Dobson circulation (BDC) and eddy-mixing processes (Gabriel et al., 2011a). This affects the zonal mean meridional transport of trace gases from the tropics to mid- 
latitudes and polar latitudes in the stratosphere and also produces variations in the strength of the polar winter vortices and stratospheric warming events (WMO, 2014). On the other hand, naturally induced ozone variability is also caused by interannual changes in solar ultraviolet spectral irradiance (Hood and McCormack, 1992). Many studies regarding the interannual variability can be found in the literature (e.g. Manzini, 2009; Fischer et al., 2008; Brönnimann, 2007; Randel and Wu, 2007; Austin et al., 2007; Calisesi and Matthes, 2007; Leblanc and McDermid, 2001; Baldwin et al., 2001; Hollandsworth et al., 1995; Brasseur, 1993). Even though a number of mechanisms have been proposed as interpretations of the natural ozone variations in previously mentioned analyses, there are still open questions in the attribution of the causes to the effects observed in the stratosphere. For instance, discrepancies between different model simulations (e.g. Fischer et al., 2008) or inconsistencies between model simulations and observations (e.g. Ball et al., 2016) in the response of ozone to a natural oscillation complicate the understanding of the cause of the observed effect. Moreover, these modes of variability do not always play a role in isolation; there are numerous examples (e.g. Garfinkel et al., 2015; Gabriel et al., 2011b; Gray et al., 2010; Hood et al., 2010; Calvo et al., 2009; White and Liu, 2008; Van Loon and Labitzke, 2000; Garcia et al., 1997) for which the interactions are known to occur, throwing more complexity into the understanding of this topic. A better comprehension of the natural oscillations would offer a better recognition and predictability of stratospheric ozone trends. As a matter of fact the knowledge of the natural ozone variations is useful to unmask effects on trends, i.e. to distinguish between natural signals and anthropogenic signals. In addition, the anthropogenic signal can influence the natural signal, for example the recently postulated changes in the Brewer-Dobson circulation (BDC) in response to increasing greenhouse gases (Butchart et al., 2006). Consequently, the understanding of ozone variability is very useful for the detection and attribution of long-term changes.

An analysis of this sort at a single station may offer valuable information, useful not only for the comprehension at regional levels but also for the validation of model simulations. In fact, Ball et al. (2016) have found that model simulations of the ozone response to solar variability are inconsistent with satellite observations. Therefore, observational studies can be very helpful to shed light on the subject. In addition, our station can contribute to the understanding of the natural oscillations since there are just a few observational studies based on ground-based stations (e.g. Nair et al., 2013; Calisesi et al., 2005; Schneider et al., 2005) of naturally induced stratospheric ozone variability in midlatitudes. The GROMOS (GROund-based Millimeter-wave Ozone Spectrometer) ozone radiometer has been performing continuous observations of stratospheric ozone profiles since 1994 above Bern $\left(46.95^{\circ} \mathrm{N}, 7.44^{\circ} \mathrm{E}\right.$; $\left.577 \mathrm{~m}\right)$. GROMOS is part in the Network for the Detection of Atmospheric Com- position Change (NDACC). Long-term ground-based measurements allow the empirical characterisation of natural cycles in stratospheric ozone as a function of altitude. In Moreira et al. (2015) we applied the multilinear parametric trend model (von Clarmann et al., 2010) to derive the long-term trend in stratospheric ozone above Bern. Here, we optimise this method to determine the basic natural oscillations in stratospheric ozone over the past 18 years. The selection of the time interval was the same as in Moreira et al. (2015), based on the assumption that the concentration of equivalent effective stratospheric chlorine (EESC) peaked in 1997 at midlatitudes (WMO, 2011). The regression model includes a linear term, the annual and semi-annual oscillation, QBO, ENSO and the solar activity cycle. Many studies use regression analyses to evaluate natural variability in the middle atmosphere (e.g. Mitchell et al., 2014; Hood et al., 2010; Randel et al., 2009; Randel and Wu, 2007; Austin et al., 2007; Hood and McCormack, 1992).

The layout of this study is as follows: the description of the data sources employed is provided in Sect 2. Details of the regression technique are given in Sect. 3. Section 4 presents a short summary of the most important processes for stratospheric ozone production and destruction. Section 5 describes the results of the analysis and provides an overview of the possible causes of the natural oscillations observed in stratospheric ozone. Finally the conclusions are summarised in Sect. 6.

\section{Data sources}

The present study is based on stratospheric ozone profiles observed by GROMOS. The instrument is a ground-based ozone microwave radiometer which is part of the NDACC. It has been continuously observing the middle atmosphere above Bern, Switzerland $\left(46.95^{\circ} \mathrm{N}, 7.44^{\circ} \mathrm{E}, 577 \mathrm{~m}\right.$ above sea level) since November 1994. It measures the thermal microwave emission of a rotational transition of ozone at 142.175 GHz. The altitude range of the retrieved ozone profiles covers 25 to $70 \mathrm{~km}$ with a vertical resolution of $8-12 \mathrm{~km}$ in the stratosphere. The measurement contribution between 50 and $0.5 \mathrm{hPa}(20$ to $52 \mathrm{~km}$ ) is higher than 0.8 (corresponding to an a priori contribution of less than $20 \%$ ); therefore the retrieved ozone values at these altitudes are primarily based on the measured line spectrum. For technical details, measurement principle and retrieval procedure on the instrument, see for example Moreira et al. (2015) and Peter (1997) and references included therein. The vertical ozone profiles from GROMOS have been validated by means of nearby ozone sondes, ground-based stations and are in good agreement with satellite observations. Its data set has been used for studies of ozone-climate interaction, middle atmospheric dynamics as well as for long-term monitoring of the stratospheric ozone layer and for the detection of trends (Moreira et al., 2015; WMO, 2014; Studer et al., 2014, 2013; Hocke 
et al., 2013; Studer et al., 2012; van Gijsel et al., 2010; Keckhut et al., 2010; Flury et al., 2009; Steinbrecht et al., 2009, 2006; Dumitru et al., 2006; Calisesi et al., 2001; Peter et al., 1996; Peter and Kämpfer, 1995).

The data used to analyse temperature, zonal wind, meridional wind and vertical wind for natural variability are from the European Centre for Medium-Range Weather Forecasts (ECMWF) operational analysis for the given location and time interval. In addition, we have also utilised temperature profiles measured by TEMPERA (temperature radiometer) microwave radiometer. This instrument was located at the University of Bern, as well as GROMOS, until the end of 2013, after which it was moved to Payerne, Switzerland $\left(46.82^{\circ} \mathrm{N}, 6.95^{\circ} \mathrm{E}, 491 \mathrm{~m}\right.$ a.s.l. and $40 \mathrm{~km}$ southwest of Bern) in the frame of a measurement campaign. TEMPERA is a novel ground-based microwave radiometer that measures the thermal radiation emitted by molecular oxygen in the microwave spectrum region in a frequency range from 51 to $57 \mathrm{GHz}$. This radiation contains information on the atmospheric temperature. This is the first radiometer that provides temperature profiles in the troposphere and in the stratosphere at the same time. In this study we only use the stratospheric temperature profiles with an altitude range of 18 $50 \mathrm{~km}(70$ to $0.7 \mathrm{hPa})$ and a vertical resolution of $15 \mathrm{~km}$, retrieved with a measurement response higher than 0.6. The TEMPERA radiometer is described in more detail in NavasGuzmán et al. (2014, 2015) and Stähli et al. (2013).

\section{Regression analysis}

The regression analysis of the time series of ozone monthly means from GROMOS and the other monthly mean products (temperature, zonal wind, meridional wind and vertical wind) from ECMWF for the period from January 1997 to January 2015 has been carried out using the following multilinear regression function:

$$
\begin{aligned}
\hat{y}(t)= & a+b \cdot t+c_{1} \cdot \mathrm{qbo}_{1}(t)+d_{1} \cdot \mathrm{qbo}_{2}(t)+e \cdot \mathrm{F} 10.7(t) \\
& +f \cdot \operatorname{MEI}(t)+\sum_{n=1}^{2}\left(g_{n} \cdot \sin \left(\frac{2 \pi \cdot t}{l_{n}}\right)+h_{n}\right. \\
& \left.\cdot \cos \left(\frac{2 \pi \cdot t}{l_{n}}\right)\right),
\end{aligned}
$$

where $t$ is the time, and $a$ and $b$ are the constant term and the linear trend of the fit. The QBO indices are $\mathrm{qbo}_{1}$ and $\mathrm{qbo}_{2}$. These terms were implemented by using the normalised Singapore zonal winds at 30 and $50 \mathrm{hPa}$. These are provided by the Free University of Berlin via http://www.geo.fu-berlin. de/met/ag/strat/produkte/qbo/index.html. The F10.7 term is the normalised time series of the solar radio flux at $10.7 \mathrm{~cm}$, which is a proxy of the solar activity cycle. Moreover, the MEI term represents the normalised Multivariate ENSO index (MEI) time series used to identify the ENSO variability during the regression analysis. Both indices are available from www.esrl.noaa.gov/psd/data/climateindices/ list. The sum term comprises 2 sine and cosine functions with the period length $l_{n}$, which represent the annual and semi-annual cycles. The usage of sine and cosine functions give access to the amplitude and the phase of each harmonic. In contrast to the harmonics and $\mathrm{QBO}$, the multilinear regression model has no access to the phase of the solar activity cycle and ENSO. This results in the detection of the instantaneous response of ozone to the solar activity cycle and ENSO. Nevertheless, we already know from the literature (e.g. Ineson and Scaife, 2009; Manzini, 2009; Brönnimann et al., 2007; Steinbrecht et al., 2004; Sassi et al., 2004; Brönnimann et al., 2004; Lee and Smith, 2003) that the impact of the solar activity cycle and ENSO in ozone have a certain time lag. In order to avoid this problem the fitting of these terms was made with a time shift (1-year delay for the solar activity cycle and 1-season delay for the ENSO). The coefficients $a, b, c_{1}, d_{1}, e, f, g_{1}, g_{2}, h_{1}$ and $h_{2}$ are fitted to the monthly means using the method of von Clarmann et al. (2010). The uncertainties of the monthly means are also required for the regression analysis. For more details on this we refer to Moreira et al. (2015).

Figure 1 shows three examples of the fit in the lower, middle and upper stratosphere $(23,10$ and $3 \mathrm{hPa})$. The ozone monthly means measured by GROMOS (blue line) and the calculated fit (red line) are represented in the first panel of each column. In the second, third and fourth panels of every column the ozone fitted signals of the proxies QBO (magenta line), solar F10.7 cm flux (red line) and ENSO (green line) are shown. Finally in the lowermost panels the residuals are represented. The residuals are within $0.5 \mathrm{ppm}$ except for some special cases. In the lower stratosphere the regression model explains about $50 \%$ of the variance whereas in the middle and upper stratosphere it explains around $80 \%$.

\section{Stratospheric ozone}

In this section, we give a brief overview of the most important processes for the photochemistry, chemistry and transport of stratospheric ozone. In 1930, Chapman postulated that ozone is formed by the photolysis of $\mathrm{O}_{2}$ at wavelengths shorter than $240 \mathrm{~nm}$ (Reaction R1), immediately followed by the recombination of atomic oxygen with molecular oxygen and any mediating air molecule $\mathrm{M}$ via the three-body Reaction (R2) (Crutzen and Oppenheimer, 2008). Ozone is removed locally by both transport and chemical processes (Yang et al., 2006). Chapman proposed the photolysis of ozone (Reactions R3 and R4) and its recombination with atomic oxygen (Reaction R5) to balance the production of ozone. The photodissociation of ozone leads to the formation of oxygen atoms in either their ground state $\left({ }^{3} P\right)$ or in their first excited state $\left({ }^{1} D\right)$ (Brasseur and Solomon, 2005). 

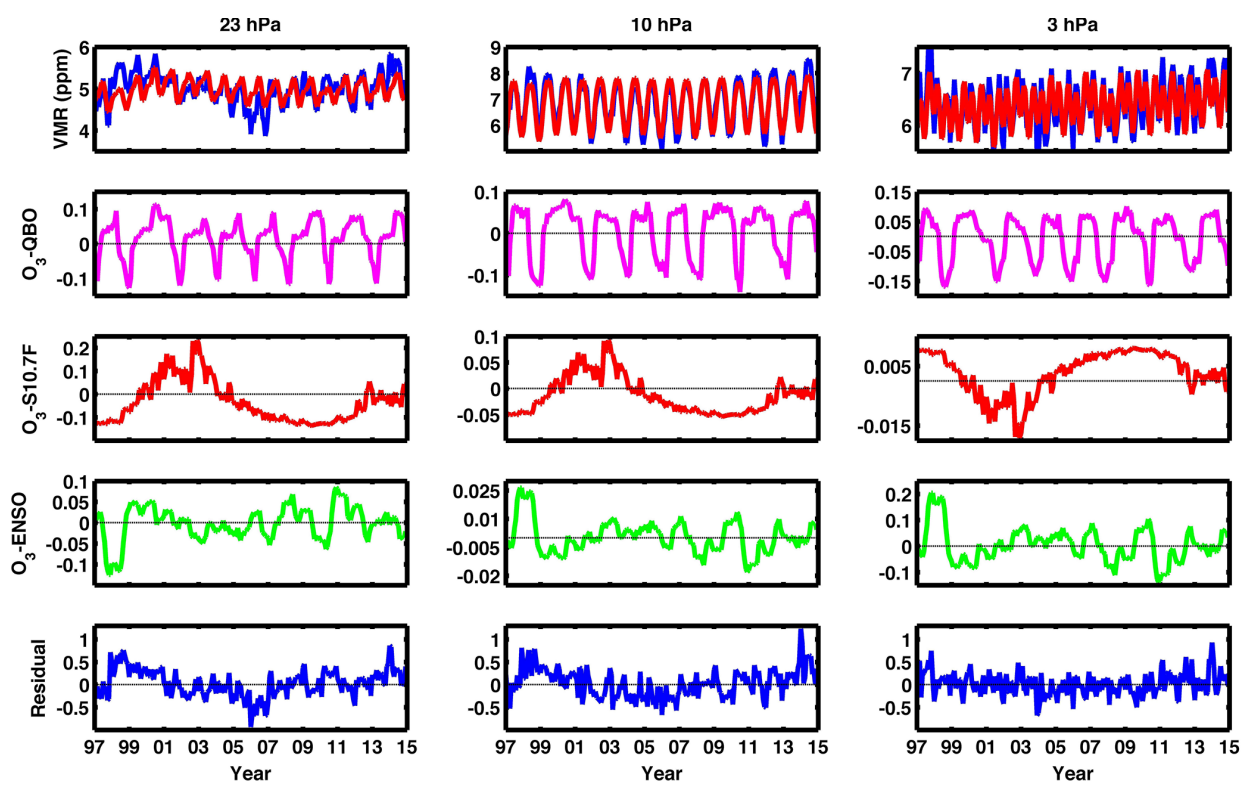

Figure 1. In the first panel of each column the GROMOS monthly means in blue and the calculated fit in red is represented. Every column represents a different pressure level, representative of the lower, middle and upper stratosphere (23, 10 and $3 \mathrm{hPa}$ respectively). In the second, third and fourth panel of each column the ozone fitted signals of the proxies QBO (magenta line), solar F10.7 cm flux (red line) and ENSO (green line) are shown. The last panel of every column shows the residuals.

$\mathrm{O}_{2}+\mathrm{h} v \rightarrow \mathrm{O}+\mathrm{O}$

$\mathrm{O}_{2}+\mathrm{O}+\mathrm{M} \rightarrow \mathrm{O}_{3}+\mathrm{M}$

$\mathrm{O}_{3}+\mathrm{h} v(\lambda \geq 320 \mathrm{~nm}) \rightarrow \mathrm{O}_{2}+\mathrm{O}\left({ }^{3} \mathrm{P}\right)$

$\mathrm{O}_{3}+\mathrm{h} v(\lambda \leq 320 \mathrm{~nm}) \rightarrow \mathrm{O}_{2}+\mathrm{O}\left({ }^{1} \mathrm{D}\right)$

$\mathrm{O}+\mathrm{O}_{3} \rightarrow \mathrm{O}_{2}+\mathrm{O}_{2}$

Because atomic oxygen and ozone molecules are rapidly interconverted, it is useful to consider both as a family: the odd-oxygen family. Since a typical timescale for meridional transport is of the order of months, the relevant quantity in this context is the concentration of odd oxygen, not that of its components. The lifetime of odd oxygen in a parcel of air is much longer than the lifetime of an individual $\mathrm{O}$ atom or $\mathrm{O}_{3}$ molecule.

The chemical lifetime of odd oxygen ranges from weeks at $30 \mathrm{~km}$ to a year at $20 \mathrm{~km}$. Therefore, odd oxygen has a sufficiently long lifetime to be influenced by meridional transport processes (Brasseur and Solomon, 2005). Consequently transport processes, for example the Brewer-Dobson circulation, contribute to the stratospheric ozone distribution.

The partitioning of odd oxygen depends upon the photolysis rate of ozone, the $\mathrm{O}+\mathrm{O}_{2}$ reaction rate coefficient and the air density. The photolysis rate generally depends on the absorption cross section of ozone and the number of incident UV photons. The number of photons in turn depends upon a number of other parameters: altitude, latitude, season and local time. All of these parameters implicitly depend on the solar zenith angle. As the seasons change from winter to summer, the solar zenith angle decreases. Therefore, the path that UV photons must travel is shorter in summer than in winter. Consequently, the photolysis rate coefficients at the upper stratosphere and lower mesosphere have maximum values during summer, when the path length is shorter, and minimum values during winter, when the path length is longer. On the other hand, the rate of photolysis depends on both the number of UV photons and the number of ozone molecules available to interact with photons.

\section{Results and discussion}

\subsection{Amplitudes of the natural oscillations}

The aim of a regression study is to reproduce the evolution through time of the variable under assessment by means of a linear combination of basic functions. To achieve this goal the regression model includes basic functions representing, in our case, the solar activity cycle, the El Niño-Southern Oscillation (ENSO), the quasi-biennial oscillation (QBO) and the annual and semi-annual oscillation. As a result of using them to fit the ozone monthly means during the regression analysis, we may also use them to quantify the natural variability of ozone. The left panel of Fig. 2 shows the amplitude of the regression coefficients of these terms in ppm, along with the ozone mean profile (green line) divided by 10 in order to plot all these quantities together, whereas in the right panel the amplitudes are plotted in percent. The magenta line 


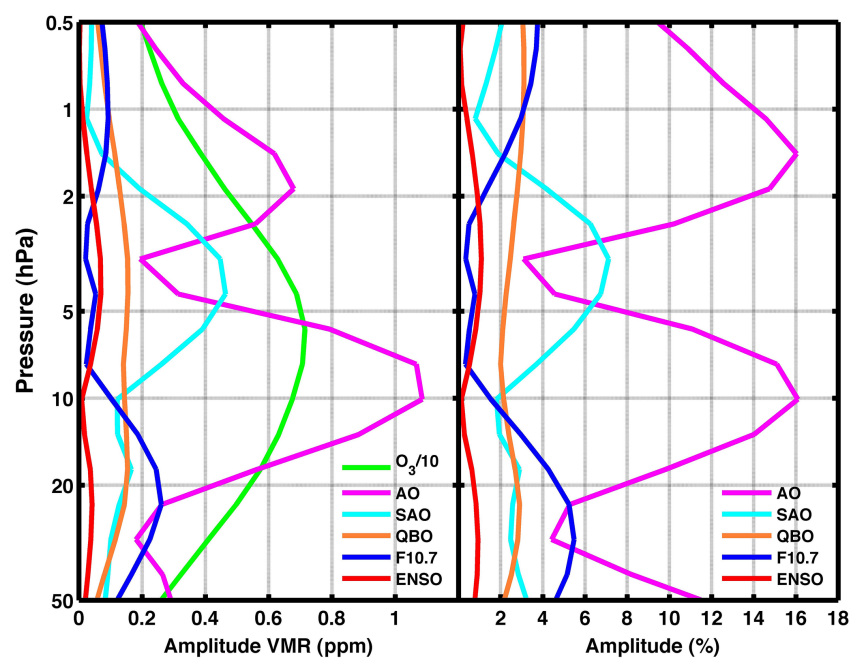

Figure 2. Amplitudes of the natural oscillations in stratospheric ozone derived by multilinear regression from the GROMOS observations at Bern (1997-2015). The ozone mean profile divided by 10 is shown by the green line.

represents the annual oscillation (AO), the semi-annual oscillation (SAO) is the cyan line, the orange line is the QBO, ENSO is the red line and the solar radio flux at $10.7 \mathrm{~cm}$ (F10.7) is represented by the blue line. The amplitude of the $\mathrm{AO}$ dominates at 10 and $2 \mathrm{hPa}$ whereas the $\mathrm{SAO}$ has its maximum at $3 \mathrm{hPa}$. Near $3 \mathrm{hPa}$ at midlatitudes, the magnitude of the SAO amplitude is larger than the magnitude of the AO amplitude. This effect is also observed by Perliski et al. (1989). After the annual cycle, the solar variability seems to be the largest source of variation in ozone, exhibiting its influence around $20 \mathrm{hPa}$. However, the observed 11-year oscillation in stratospheric ozone observed by GROMOS microwave radiometer could be influenced by interfering processes which we will discuss later.

\subsection{Annual oscillation (AO)}

In the middle stratosphere our observations indicate maximum ozone concentrations in spring-summer and a minimum during autumn-winter. The amplitude of the maximum at $10 \mathrm{hPa}(32 \mathrm{~km})$ is of the order of $16 \%$ (blue line in Fig. 3, right panel) or around $1 \mathrm{ppm}$ (magenta line in Fig. 2, left panel). On the other hand in the upper stratosphere during the spring-summer period we observe a minimum and a maximum in autumn-winter. This maximum has a peak amplitude around $0.6 \mathrm{ppm}$ (magenta line in Fig. 2, left panel) or over $16 \%$ (blue line in Fig. 3, right panel) over $2 \mathrm{hPa}(42 \mathrm{~km})$. Our results are in agreement with other observational and modelling studies (Eckert et al., 2014; Calisesi et al., 2005; Schneider et al., 2005; Perliski et al., 1989). For instance, Schneider et al. (2005) obtained a maximum AO-amplitude of the order of $15 \%$ at $26 \mathrm{~km}$ and around $18 \%$ at $40 \mathrm{~km}$ with observations between 1995 and 2002 from the Bordeaux mi-
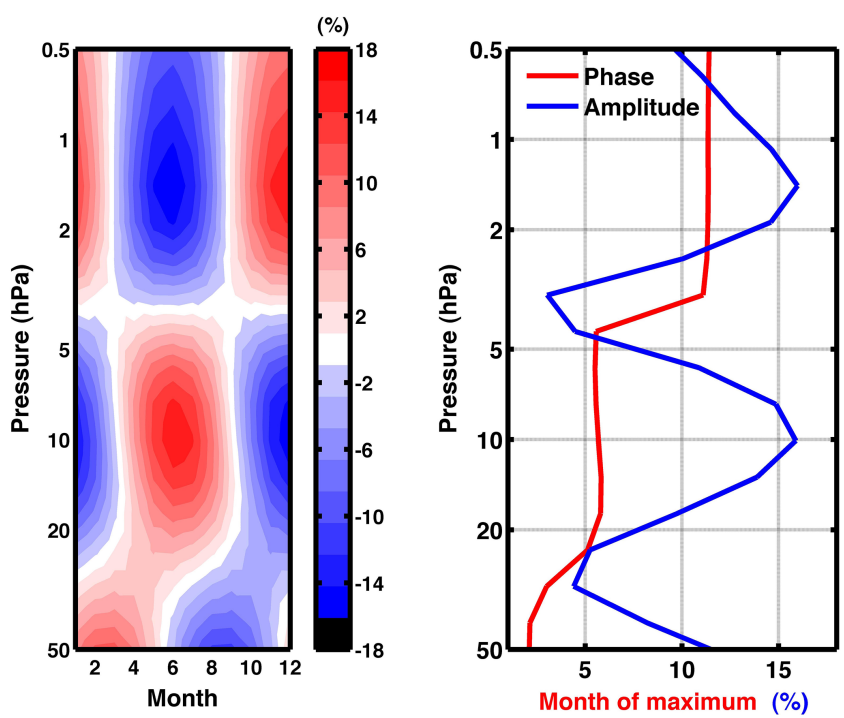

Figure 3. The amplitude of the ozone-AO depending on the months of the year is represented in $\%$ in the left panel. The profile of the amplitude of ozone-AO in \% (blue line) and its phase given as the month of the maximum (red line) is shown in the right panel.

crowave radiometer. Further, we are in agreement with the results of Eckert et al. (2014), who used the same regression technique as us, but data from MIPAS on ENVISAT for the period of July 2002 to April 2012. The seasonal variation of ozone can be understood through the partitioning of odd oxygen. Due to the higher flux of shortwave radiation in summer more odd oxygen would be expected in the upper stratosphere. The main reason for the minimum ozone in summer in the upper stratosphere is known to be the temperaturedependent photochemistry. The temperature-induced ozone change is principally dominated by the $\mathrm{NO}_{x}, \mathrm{ClO}_{x}$ and $\mathrm{HO}_{x}$ catalytic ozone destruction cycles (Flury et al., 2009) and also by Reaction (R5) (Schanz et al., 2014), which is sensitive to temperature variations. As a result, ozone depletion is higher in summer than in winter at the stratopause as we can see in Fig. 3; the annual ozone maximum around $2 \mathrm{hPa}$ occurs in winter. This feature shows the anti-correlation of ozone and temperature in the stratopause region. After the equinox, when temperatures start to be warmer the oddhydrogen and odd-oxygen reactions proceed faster and ozone is destroyed more rapidly. During wintertime, when temperatures are lower, these reactions proceed more slowly, causing the ozone density to increase (Perliski et al., 1989).

Below the upper stratosphere the anti-correlation of ozone and temperature breaks down, partly because of the small concentration of atomic oxygen and the high air density at lower altitudes where atomic oxygen immediately converts into ozone by Reaction (R2). Indeed, Fig. 3 clearly shows a phase reversal of the ozone- $\mathrm{AO}$ at $3 \mathrm{hPa}$, where the partitioning of odd oxygen is balanced by the change from more abundance of atomic oxygen above $3 \mathrm{hPa}$ to more abundance 


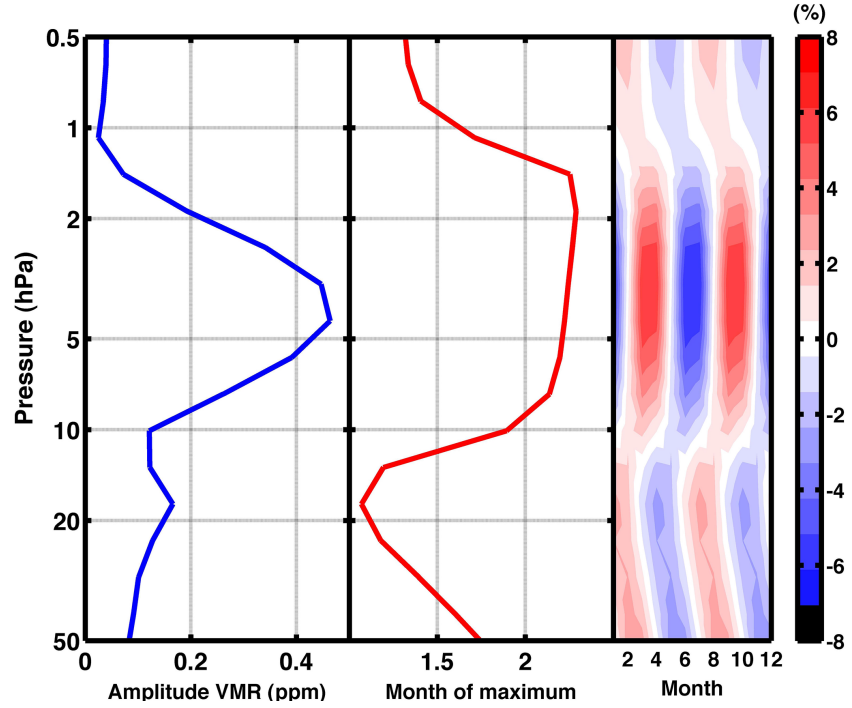

Figure 4. The profile of the amplitude of ozone-SAO in ppm (blue line) and its phase given as the month of the maximum (red line) are shown in the left and middle panel. The amplitude of the ozoneSAO depending on the months of the year is represented in $\%$ in the right panel.

of ozone below $3 \mathrm{hPa}$. Perliski et al. (1989) suggested that the dominant cause of annual ozone amplitude is the annual variation in the production rate of odd oxygen. In the middle and lower stratosphere, the production rate of odd oxygen is roughly equal to the production rate of ozone because of Reaction (R2). This explains the summer ozone maximum when the production rate of odd oxygen is maximal. Figure 2 (magenta line, left panel) and Fig. 3 (blue line) show that the annual ozone maximum at $10 \mathrm{hPa}$ occurs during early summer. The red line in Fig. 3 represents the phase of the ozone-AO given as the month of maximum, and in the ozone$\mathrm{AO}$ maximum at $10 \mathrm{hPa}$ we can clearly see the phase (red line) around 5-6 months, i.e. May-June (early summer). This summer ozone maximum is also influenced by the meridional transport of ozone-rich air from the tropics (Cordero and Kawa, 2001).

\subsection{Semi-annual oscillation (SAO)}

The semi-annual oscillation (SAO) has a period of 6 months. The ozone-SAO amplitude maximum is around $3 \mathrm{hPa}(40 \mathrm{~km})$ and exhibits its maximum of slightly over $0.4 \mathrm{ppm}$ (blue line in Fig. 4, left panel) or around $7 \%$ (cyan line in Figure 2, right panel). Calisesi et al. (2005) obtained the same order of magnitude for the amplitude of ozoneSAO calculated through an iterative spectral analysis with data from GROMOS for the period 1994-2004. By using the same regression method and data (July 2002-April 2012) from MIPAS Eckert et al. (2014) got an ozone-SAO amplitude for our latitude around $0.3 \mathrm{ppmv}$ at $40 \mathrm{~km}$. Huang et al. (2008) showed an amplitude of ozone-SAO of the order

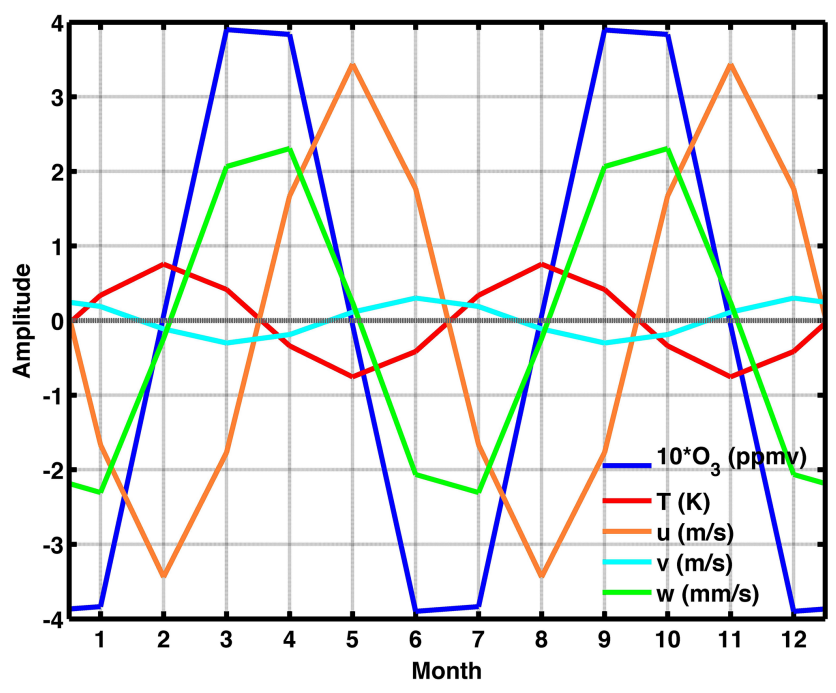

Figure 5. Amplitude of the temperature-, zonal wind-, meridional wind-, vertical wind-, ozone-SAO throughout the year at $3 \mathrm{hPa}$. The ozone-SAO is multiplied by 10 .

of $0.3 \mathrm{ppmv}$ around $40 \mathrm{~km}$ and at $40^{\circ} \mathrm{N}$ latitude with measurements from SABER (Sounding of the Atmosphere using Broadband Emission Radiometry) for the period 2002-2005. On the other hand, Perliski et al. (1989) found an SAO amplitude of about $0.5 \mathrm{ppmv}$ around $3 \mathrm{hPa}$ with 9 years (October 1978-September 1987) of SBUV (Solar Backscatter U1traviolet) ozone-mixing ratio data. The middle panel of Fig. 4 shows the phase of ozone-SAO, the month of the maximum is between 3.5 and 4 months at $3 \mathrm{hPa}$, within the period of the SAO. This can be confirmed in the right panel of Fig. 4, where the ozone-SAO amplitude is represented against the months of the year. These peak amplitudes coincide in time with the equinoxes, whereas the minima coincide with the solstices. The most interesting point about the ozone-SAO is that its maximal amplitude is located in the same altitude region (upper stratosphere) as the maximal anti-correlation between ozone and temperature (Calisesi et al., 2001).

In order to understand the ozone-SAO, we have also performed a regression analysis for temperature, zonal wind, meridional wind and vertical wind, all of them from the ECMWF operational analysis data over Bern. Since the purpose of this study is to explain the natural variations of ozone only, we are not going to provide explanations for the ECMWF products used but we take them as given. Figure 5 shows the semi-annual cycle at $3 \mathrm{hPa}$ along the year. The amplitude of the temperature (red line), zonal wind (orange line), meridional wind (cyan line), vertical wind (green line) and ozone (blue line)-SAO are plotted together in order to have an overview of which parameter or parameters play a major role in the ozone-SAO. In Fig. 5 the ozone-SAO amplitude is multiplied by 10 . The ozone-SAO is 1.5 month out of phase with that of temperature in the upper stratosphere. This is consistent with ozone photochemistry (Ray et al., 1994). 


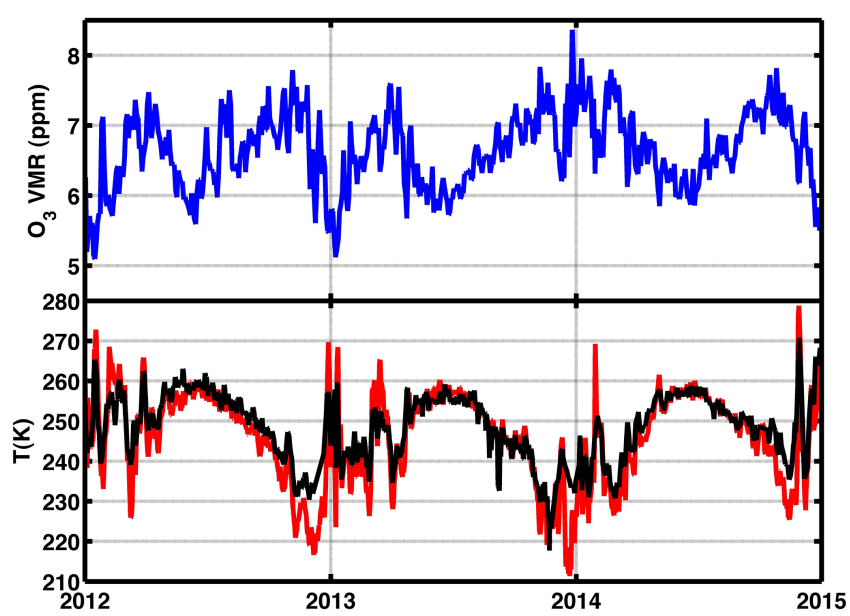

Figure 6. Ozone VMR from GROMOS (blue line), temperature from TEMPERA (black line) and ECMWF (red line) at $3 \mathrm{hPa}$ for the period from January 2012 to January 2015.

At $3 \mathrm{hPa}$, the first positive maximum of ozone occurs at the beginning of March, 1 month after the time of the first SAOtemperature maximum. The stratopause zonal wind-SAO is characterised by the occurrence of easterly winds during the solstice seasons and westerly winds during the equinoxes. The warm phase descends with the easterly shear zone in the solstice season. The cold phase descends with the westerly shear zone around the equinox. The zonal wind reversal of the SAO from westward to eastward wind is likely driven by gravity waves. Otherwise, zonal wind reversal from SAO eastward to westward wind is assumed to be mainly driven by horizontal advection and meridional momentum transport of extratropical planetary waves (Ern et al., 2015). High-speed Kelvin wave, gravity wave propagation into the upper stratosphere and the resultant deposition of eddy zonal momentum are thought to be the most significant forcing of the westerly acceleration (Ray et al., 1994). The out-of-phase relationship between temperature and vertical wind (upwelling $(w>0)$, green line in Fig. 5) is expected due to adiabatic cooling associated with the ascent of ozone-rich air. Therefore, the ozone maximum is found during the equinoxes at $3 \mathrm{hPa}$, as shown in Fig. 5.

Easterly accelerations, on the other hand, appear to be forced meridionally by planetary waves and meridional advection (Ray et al., 1994). During wintertime planetary wave breaking in the upper stratosphere is observed, producing poleward transport and a downward flow $(w<0$, green line in Fig. 5). The downwelling, through air compression, yields an increase in the temperature. The anti-correlation of ozone and temperature is maximal around $3 \mathrm{hPa}$ (upper stratosphere) during winter over Bern (Calisesi et al., 2001). In Fig. 6, we observe that an increase in temperature of around $20-30 \mathrm{~K}$ causes a decrease in ozone volume-mixing ratios in winter of the order of 1-1.5 ppmv. Figure 6 shows the ozone VMR (volume mixing ratio) from GROMOS (blue line), the temperature from TEMPERA radiometer (black line) and the temperature from ECMWF operational data (red line) near $3 \mathrm{hPa}$ for the period between January 2012 and January 2015. The good agreement between the temperature from TEMPERA and from ECMWF at this altitude is clearly seen in Fig. 6. We observe the two-peaked ozone curve in each calendar year (ozone-SAO), the minima in ozone during wintertime and summertime and the maxima during spring and autumn. Regarding the temperature, we notice the fluctuations during wintertime, the increase in spring- and summertime and the decrease after the summer solstice. The aforementioned anti-correlation of ozone and temperature is clearly visible, displayed by the upper stratospheric warming events and the associated ozone decrease in winter. These stratospheric warming events in winter are related to planetary wave breaking (PWB). Planetary waves can break and cause disruptions to the polar vortex and rapid warmings of the stratosphere. The occurrence of warming events are even more frequent in the upper stratosphere compared to the mid-stratosphere as the climatology study by Greer et al. (2013) showed. Thus, the upper stratospheric warmings contribute to the temperature-SAO and the latter contributes to the ozone-SAO. A possible role of stratospheric warmings for the generation of the ozone-SAO at midlatitudes was previously mentioned by Perliski et al. (1989) and Maeda (1984). Calisesi et al. (2001) and Flury et al. (2009) showed that the strongest oscillations of ozone above Bern are because of displacements of the polar vortex by planetary wave breaking. The temperature-induced ozone change is mainly dominated by the $\mathrm{NO}_{x}$ catalytic ozone destruction cycle, Reaction (R5) and in lesser extent by Reaction (R2), which are sensitive to temperature variations (Schanz et al., 2014; Flury et al., 2009). The rate of $\mathrm{NO}_{x}$ cycle and Reaction (R5) increases when the temperature rises whereas the rate of Reaction (R2) slows down as the temperature increases. Furthermore, the observed summertime amplitude dip in ozone (blue line in Fig. 5) is also due to warming; in this case to the increase of temperature in summer. The ozone destruction rates are accelerated during spring as the temperature rises, causing the observed amplitude drop in ozone after March.

\subsection{Quasi-biennial oscillation (QBO)}

The quasi-biennial oscillation (QBO) dominates the variability of the equatorial stratosphere and is easily identified as an alternation of descending westerly and easterly wind regimes, with a variable average period length of approximately 28 months. Even though the QBO is a tropical phenomenon, it affects the stratospheric flow from pole to pole and consequently some chemical constituents such as ozone are affected through modulation of extratropical wave propagation induced by the QBO (Baldwin et al., 2001). The QBO was implemented in the multilinear parametric trend model (von Clarmann et al., 2010) using the Singapore zonal winds at 30 and $50 \mathrm{hPa}$ as a proxy, which are approximately phase- 


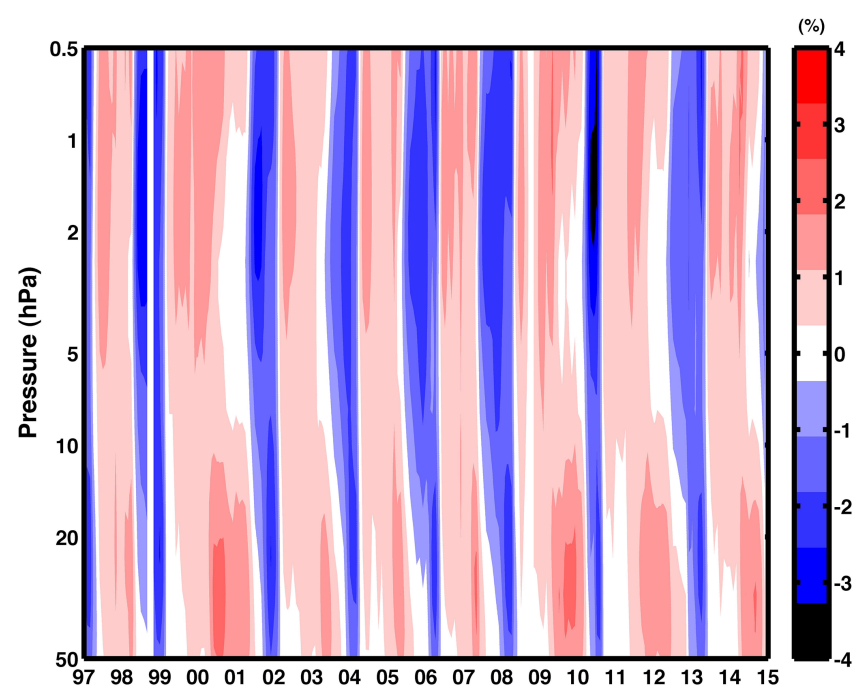

Figure 7. Amplitude of the ozone-QBO determined by multilinear regression for the time interval from January 1997 to January 2015.

shifted by a quarter period so that they are sine and cosine functions of the same period (28.8 months) (Eckert et al., 2014). Their combination can emulate any QBO phase shift (Kyrölä et al., 2010). Stiller et al. (2012) were the first to use the QBO proxies in this multilinear parametric trend model. In Fig. 7 and in Fig. 2 (orange line) we can observe that the amplitude of the ozone-QBO maximum is located around $0.15 \mathrm{ppmv}$ (not exceeding $3 \%$ ) near $30 \mathrm{hPa}(24 \mathrm{~km})$. Our results are in relatively good agreement with those of Calisesi et al. (2005), with ozone-QBO amplitudes of about $5 \%$ at $25 \mathrm{~km}$ for the period 1994-2004. These findings also agree with those by Eckert et al. (2014), who obtained an ozoneQBO amplitude of slightly over 0.2 ppmv in our latitude region at $25 \mathrm{~km}$ between 2002 and 2012. During the easterly (westerly) shear zone of the Singapore zonal winds the amplitude of ozone-QBO observed in Fig. 7 is positive (negative). This effect is related to the QBO-induced meridional circulation and confirms the midlatitude ozone-QBO out of phase relationship with the equatorial ozone-QBO. The amplitude of the equatorial ozone-QBO is positive (negative) during the westerly (easterly) shear zone (Leblanc and McDermid, 2001; Baldwin et al., 2001; Hollandsworth et al., 1995).

The meridional circulation affects chemical tracers such as ozone and gives rise to strong ozone-QBO signals in such tracers at all latitudes (Baldwin et al., 2001). Some models and observational studies (Leblanc and McDermid, 2001; Baldwin et al., 2001; Hollandsworth et al., 1995) found that the downward (upward) vertical motion in the equatorial westerly (easterly) shear zone induces an increase (decrease) in ozone whereas in the midlatitudes it induces a decrease (increase) in ozone, which we observe in our study.

\subsection{Solar activity cycle}

The solar radiation between 200 and $240 \mathrm{~nm}$ is primarily responsible for the formation of ozone in the stratosphere. Changes in solar UV spectral irradiance directly modify the production rate of ozone in the upper stratosphere. The solar activity cycle is dominated by an 11-year solar cycle. The solar activity cycle effect on upper stratospheric ozone is a direct consequence of heating and photochemistry (Reactions $\mathrm{R} 1$ and $\mathrm{R} 2$ and $\mathrm{NO}_{x}$ cycle). The lower stratospheric response in ozone occurs mainly by means of a dynamical response to solar UV variations (WMO, 2014). Further, the 11-year solar cycle influence on planetary wave propagation will influence the strength of the polar vortex as well as the strength of the mean meridional Brewer-Dobson (BD) circulation since this is forced by planetary wave transfer of momentum. Therefore, a solar cycle variation in ozone amount is to be expected (Mitchell et al., 2014). In order to take into account the effect of solar activity cycle in the stratospheric ozone, a time series of the normalised solar radio flux at $10.7 \mathrm{~cm}$, which is a proxy of the solar activity, was fitted to the ozone monthly means during the regression analysis. Stratospheric ozone has a delayed response to the solar activity cycle (e.g. Steinbrecht et al., 2004; Lee and Smith, 2003). Therefore, in order to estimate this time lag we checked the time series of total ozone above Arosa (Switzerland) for the four solar activity cycles from 1953 to 1996 . Generally, the ozone maxima seem to have lagged around 1 year after the solar maximum regarding the time series of solar radio flux at $10.7 \mathrm{~cm}$. Further, Steinbrecht et al. (2004) mentioned a lag of about 1 year behind the maxima of the $10.7 \mathrm{~cm}$ solar radio flux time series for ozone profiles measured at Hohenpeissenberg (Germany). Accordingly, we have performed the regression analysis by shifting the solar activity cycle proxy 1 year.

In Fig. 8 the normalised time series of the monthly mean $10.7 \mathrm{~cm}$ solar radio flux (green line) is represented along with the amplitude of the response in ozone to this proxy between January 1997 and January 2015. We can observe the increase in ozone volume-mixing ratio in the stratosphere during periods of increased solar activity, and the opposite during the solar minimum. The amplitude of the 11-year response in ozone is of the order of $5 \%$ or $0.25 \mathrm{ppmv}$ in the lower stratosphere and around $3 \%$ or smaller than $0.1 \mathrm{ppmv}$ in the stratopause (blue line in Fig. 2). The result in the lower stratosphere is in agreement with the study by Calisesi et al. (2005), in which they studied the natural variability of stratospheric ozone from GROMOS for the time interval between 1994 and 2004 with an iterative spectral analysis. Additionally, Steinbrecht et al. (2004) found a peak-to-peak amplitude up to $7 \%$ of ozone variation from DIAL data at Hohenpeissenberg related to the 11-year solar cycle over the time period 1979 to early 2003.

Observational studies (Van Loon and Labitzke, 2000) indicate a large solar influence in the lower stratosphere as a 


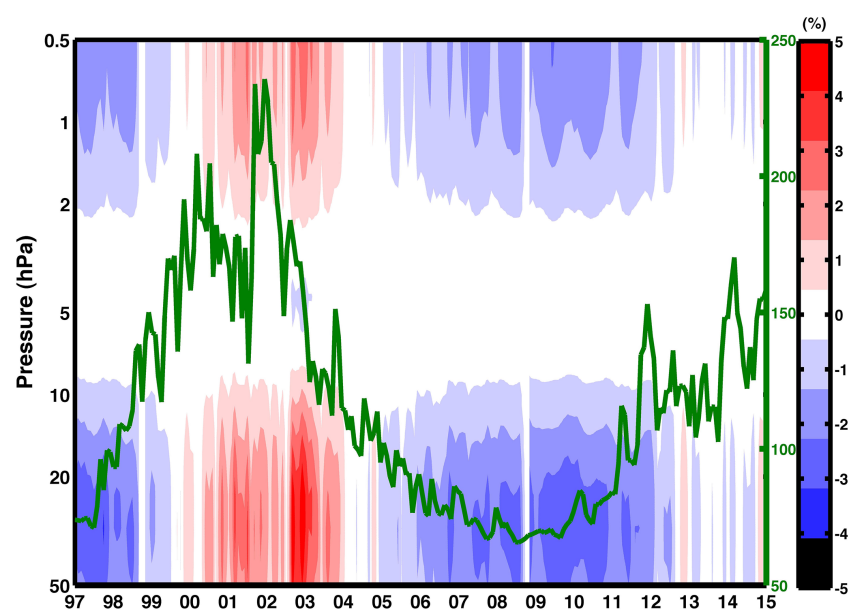

Figure 8. Amplitude of the ozone-solar F10.7 flux fitted by multilinear regression for the time interval from January 1997 to January 2015 . The green line represents the time series of the monthly mean $10.7 \mathrm{~cm}$ solar radio flux as a measure of the solar activity.

dynamic result of the interaction in the upper stratosphere between ozone and UV radiation. With our data set we obtain a smaller solar influence at the stratopause compared with the lower stratosphere. This makes sense since the increased absorption of solar irradiance during the solar maximum increases the temperature but also increases the production of ozone, which is the main absorber of radiation in this altitude region. In turn the temperature-dependent ozone photochemistry (anti-correlation between temperature and ozone) may partly compensate the solar irradiance influence at the stratopause. Kodera and Kuroda (2002) suggested that the impact the solar radiation has on the upper atmosphere and stratopause region influences the lower stratosphere through modulation of the internal mode of variation in the polar night jet and a change in the Brewer-Dobson circulation.

Various mechanisms have been proposed for the 11-year solar cycle influence on ozone variability. For instance, a change in mean meridional lower stratospheric dynamics between solar maximum and solar minimum may be the main factor for the ozone variability due to the solar activity signal. This change in ozone transport is supported by model and observational results (Mitchell et al., 2014; Calisesi and Matthes, 2007, and references therein). Model simulations (Gabriel et al., 2011b) show that zonal asymmetries in ozone, water vapour and temperature fields are modulated by the 11-year solar cycle, providing a link between the solar cycle, zonal asymmetries, planetary waves and the Brewer-Dobson circulation, all of them affecting the stratospheric ozone distribution (WMO, 2014).

The surprisingly strong ozone amplitude observed by GROMOS (5\% in the lower stratosphere) cannot be explained solely by the solar activity cycle. We hypothesise that the solar variability is in competition with other factors and together they emphasise the solar cycle response in ozone at this station. For example, strong ozone anomalies resulting from other factors may enhance the ozone anomaly related to the solar activity cycle. Our study only considers a time interval of about 1.5 cycles of the solar activity. Thus, the derived 11-year amplitude could be influenced by ozone anomalies of other reasons which may accidentally occur during the solar maximum or the solar minimum phase. Gabriel et al. (2011b) stated that the understanding of observed local changes may be improved if the change in regional wave patterns and associated mixing processes induced by the solar cycle are taken into account. Moreover, there is a lack of long-term observational studies on the response of ozone to the solar cycle in the midlatitudes.

However the exact mechanism of the dynamical response to solar cycle variations is not fully understood and cannot be reproduced fully by chemistry-climate models (WMO, 2014). On the other hand, Offermann et al. (2015) have proposed self-sustained oscillators in the atmosphere for the first time to support the theory that the oscillations they studied are excited internally in the atmosphere. They stated that the periods and phases observed might be interpreted as synchronisation effects that are typical of non-linear oscillators. The connection with our study relies on the fact that both analyses are performed in Europe, in the middle atmosphere and at the same periods of oscillation. A self-excited oscillator might explain our strong amplitude in the response of ozone related to the 11-year period. Nevertheless, this is a novel interpretation which needs further analysis and with our experimental data we cannot prove the theory.

\subsection{El Niño-Southern Oscillation (ENSO)}

El Niño-Southern Oscillation (ENSO) is the globally dominating mode of interannual climate variability and an important driver for modulating the stratospheric climate in the Northern Hemisphere (NH). ENSO-forced variations in tropical upwelling lead to temperature and water vapour variations in the tropical lower stratosphere and impact the chemistry and transport of ozone. Atmospheric teleconnections lead to ENSO-related effects on the strength of planetary waves and the Brewer-Dobson circulation, both affecting the distribution of stratospheric ozone at middle and high latitudes (WMO, 2014). Particularly at midlatitudes, the ENSO effects have a longitudinal variability (Fischer et al., 2008). Observational studies show that warm ENSO events are associated with a weak and warm polar vortex over the Arctic during wintertime (van Loon and Labitzke, 1987). During the warm ENSO winters, enhanced planetary wave activity propagates from the troposphere to the stratosphere where it decelerates the zonal mean flow and accelerates the meridional (poleward) transport (Brönnimann, 2007).

We used the Multivariate ENSO index (MEI) as a proxy of the El Niño-Southern Oscillation (ENSO) signal. The MEI index monitors the ENSO phenomenon with six variables 


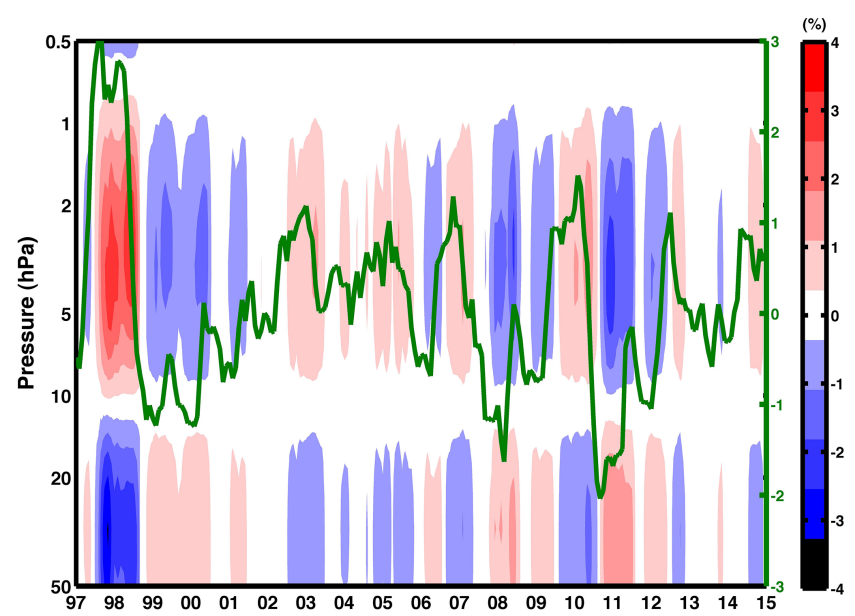

Figure 9. Amplitude of the ozone-ENSO fitted during multilinear regression for the time interval from January 1997 to January 2015. The green line represents the MEI index.

(sea-level pressure, zonal and meridional components of the surface wind, sea surface temperature, surface air temperature and total cloudiness fraction of the sky). Due to the delayed response of the ENSO signal in the northern extratropical atmosphere we have performed the regression analysis with a time lag of 1 season in the MEI index. The northern ENSO effects manifest from late winter to early spring, i.e. 1 season delayed regarding the tropical ENSO, and this is supported by observational and modelling studies (e.g. Ineson and Scaife, 2009; Manzini, 2009; Brönnimann et al., 2007; Sassi et al., 2004; Brönnimann et al., 2004).

In Fig. 9 the amplitude of the ozone-ENSO for the time interval since January 1997 to January 2015 is represented. Even though the amplitude of the ozone-ENSO is quite small, for most of the altitude range around $1 \%$ (red line in Fig. 2) we can clearly observe the response in ozone at northern midlatitudes due to ENSO, especially the strong ENSO event in 1997-1998 (Fig. 9). The main feature is the opposite phase between the amplitudes of ozone-ENSO in the lower and middle stratosphere. The green line in Fig. 9 represents the MEI index, which is positive during the warm El Niño phase (wENSO) and negative during the cold La Niña phase (cENSO). The amplitude of ozone-ENSO decreases (increases) during wENSO (cENSO) in the lower stratosphere while it increases (decreases) in the middle stratosphere. This feature is also observed over Europe in the study by Fischer et al. (2008) by the SOCOL chemistryclimate model. The mechanism which explains this pattern is a strengthening of the residual mean circulation caused by anomalously vertically propagating waves (Fischer et al., 2008, and references therein).

\section{Conclusions}

Stratospheric ozone profiles for the period 1997-2015 from GROMOS were used to evaluate the effects on ozone due to naturally induced oscillations. To perform the study, we used a multilinear parametric regression model. We derived the behaviour of the natural oscillations in stratospheric ozone, which are mainly induced by the annual and semi-annual cycles, the QBO, ENSO and the solar activity cycle. The effects on middle and upper stratospheric ozone are primarily caused by annual and semi-annual oscillations. Our observed $\mathrm{AO}$ dominates in summertime at $10 \mathrm{hPa}(32 \mathrm{~km})$ and in wintertime over $2 \mathrm{hPa}(42 \mathrm{~km})$ with amplitudes around 1 and $0.6 \mathrm{ppm}$ respectively. The $\mathrm{SAO}$ has its maximum amplitude of approximately $0.4 \mathrm{ppm}$ in springtime at $3 \mathrm{hPa}(40 \mathrm{~km})$. We found a link between the upper stratospheric SAO in winter and the polar winter stratopause warmings since the temperature enhancement due to these warmings led to upper stratospheric ozone depletion. At this altitude range, the ozone variability is mainly controlled by photochemistry since its lifetime is relatively short. Therefore, the main causes of natural oscillations in ozone in the middle and upper stratosphere arise from the temperature-dependent ozone photochemistry. On the other hand, the effects observed in the lower and middle stratosphere are owed to interannual variations of the atmospheric circulation and the solar radiation. As interannual variations we consider the QBO, ENSO and the solar activity cycle. In the lower and middle stratosphere, the long lifetime of ozone is responsible for changes in ozone that are predominantly due to transport. We identify the induced meridional circulation driven by the different phases of the aforementioned interannual variations as the primary source of effects in ozone due to transport processes. The planetary wave propagation is affected by these interannual variations and in turn will influence the strength of the mean meridional circulation. The effect of QBO in lower stratospheric ozone increases (decreases) during the westerly (easterly) phase of the Singapore zonal winds. Thereby, the response of stratospheric ozone to the QBO above the midlatitude station in Bern is opposed to that of tropical stratospheric ozone. The amplitude of the ozone-QBO at Bern is approximately $3 \%$ in the lower stratosphere. On the other hand, we note an increase (reduction) in ozone during the solar maxima (minima) period. The strong amplitude of about $5 \%$ for the observed solar cycle effect at Bern might be partly due to accidentally superposed ozone anomalies of meteorological reason or to an unknown amplification mechanism. The observed influence of ENSO on stratospheric ozone above Bern has an amplitude up to $1 \%$. During wENSO (cENSO) our results show a diminution (rise) in ozone-mixing ratios in lower stratosphere. On the contrary, in the middle stratosphere we notice an increase (decrease) for wENSO (cENSO). Our empirical results are in agreement with other model and observational studies. Nonetheless, with this study we present a new perspective of the nat- 
ural oscillation of stratospheric ozone from a northern midlatitude station, which is very useful for the identification of regional effects and also for the validation of other studies.

\section{Data availability}

The data from the GROMOS microwave radiometer is available via http://ftp.cpc.ncep.noaa.gov/ndacc/station/bern/hdf/ mwave.

Acknowledgements. This work was supported by the Swiss National Science Foundation under grant 200020 - 160048 and MeteoSwiss GAW Project: "Fundamental GAW parameters measured by microwave radiometry".

Edited by: G. Brasseur

Reviewed by: E. Remsberg and one anonymous referee

\section{References}

Austin, J., Hood, L. L., and Soukharev, B. E.: Solar cycle variations of stratospheric ozone and temperature in simulations of a coupled chemistry-climate model, Atmos. Chem. Phys., 7, 16931706, doi:10.5194/acp-7-1693-2007, 2007.

Baldwin, M. P., Gray, L. J., Dunkerton, T. J., Hamilton, K., Haynes, P. H., Randel, W. J., Holton, J. R., Alexander, M. J., Hirota, I., Horinouchi, T., Jones, D. B. A., Kinnersley, J. S., Marquardt, C., Sato, K., and Takahashi, M.: The quasi-biennial oscillation, Rev. Geophys., 39, 179-229, doi:10.1029/1999RG000073, 2001.

Ball, W. T., Haigh, J. D., Rozanov, E. V., Kuchar, A., Sukhodolov, T., Tummon, F., Shapiro, A. V., and Schmutz, W.: High solar cycle spectral variations inconsistent with stratospheric ozone observations, Nat. Geosci., 9, 206-209, doi:10.1038/ngeo2640, 2016.

Brasseur, G.: The response of the middle atmosphere to long-term and short-term solar variability: A two-dimensional model, J. Geophys. Res., 98, 23079-23090, 1993.

Brasseur, G. P. and Solomon, S.: Aeronomy of the middle atmosphere: chemistry and physics of the stratosphere and mesosphere, vol. 32 of Atmospheric and Oceanographic Science Library, Springer Science, 2005.

Brönnimann, S.: Impact of El Niño-Southern Oscillation on European climate, Rev. Geophys., 45, RG3003, doi:10.1029/2006RG000199, 2007.

Brönnimann, S., Luterbacher, J., Staehelin, J., Svendby, T., Hansen, G., and Svenøe, T.: Extreme climate of the global troposphere and stratosphere in 1940-42 related to El Nino, Nature, 431, 971-974, 2004.

Brönnimann, S., Xoplaki, E., Casty, C., Pauling, A., and Luterbacher, J.: ENSO influence on Europe during the last centuries, Clim. Dynam., 28, 181-197, 2007.

Butchart, N., Scaife, A., Bourqui, M., De Grandpré, J., Hare, S., Kettleborough, J., Langematz, U., Manzini, E., Sassi, F., Shibata, K., et al.: Simulations of anthropogenic change in the strength of the Brewer-Dobson circulation, Clim. Dynam., 27, 727-741, 2006.
Calisesi, Y. and Matthes, K.: The Middle Atmospheric Ozone Response to the 11-Year Solar Cycle, Springer New York, 23, 273 286, doi:10.1007/978-0-387-48341-2_22, 2007.

Calisesi, Y., Wernli, H., and Kämpfer, N.: Midstratospheric ozone variability over Bern related to planetary wave activity during the winters 1994-1995 to 1998-1999, J. Geophys. Res.-Atmos., 106, 7903-7916, doi:10.1029/2000JD900710, 2001.

Calisesi, Y., Hocke, K., and Kämpfer, N.: The natural variability of stratospheric and mesospheric ozone as observed over Switzerland by a ground-based microwave remote sensor, Memorie della Societ Astronomica Italiana, Journal of the Italian Astronomical Society, 76, 937-940, 2005.

Calvo, N., Giorgetta, M. A., Garcia-Herrera, R., and Manzini, E.: Nonlinearity of the combined warm ENSO and QBO effects on the Northern Hemisphere polar vortex in MAECHAM5 simulations, J. Geophys. Res.-Atmos., 114, D20, doi:10.1029/2008JD011445, 2009.

Chapman, S.: A theory of upper-atmospheric ozone, Mem. R. Metrol. Soc., 3, 103-125, 1930.

Cordero, E. C. and Kawa, S. R.: Ozone and tracer transport variations in the summer northern hemisphere stratosphere, J. Geophys. Res.-Atmos., 106, 12227-12239, doi:10.1029/2001JD900004, 2001.

Crutzen, P. and Oppenheimer, M.: Learning about ozone depletion, Climatic Change, 89, 143-154, doi:10.1007/s10584-008-9400-6, 2008.

Delisi, D. P. and Dunkerton, T. J.: Seasonal Variation of the Semiannual Oscillation, J. Atmos. Sci., 45, 2772-2787, doi:10.1175/1520-0469(1988)045<2772:SVOTSO>2.0.CO;2, 1988.

Dumitru, M., Hocke, K., Kämpfer, N., and Calisesi, Y.: Comparison and validation studies related to ground-based microwave observations of ozone in the stratosphere and mesosphere, J. Atmos. Sol.-Terr. Phys., 68, 745-756, doi:10.1016/j.jastp.2005.11.001, 2006.

Eckert, E., von Clarmann, T., Kiefer, M., Stiller, G. P., Lossow, S., Glatthor, N., Degenstein, D. A., Froidevaux, L., GodinBeekmann, S., Leblanc, T., McDermid, S., Pastel, M., Steinbrecht, W., Swart, D. P. J., Walker, K. A., and Bernath, P. F.: Drift-corrected trends and periodic variations in MIPAS IMK/IAA ozone measurements, Atmos. Chem. Phys., 14, 25712589, doi:10.5194/acp-14-2571-2014, 2014.

Ern, M., Preusse, P., and Riese, M.: Driving of the SAO by gravity waves as observed from satellite, Ann. Geophys., 33, 483-504, doi:10.5194/angeo-33-483-2015, 2015.

Fischer, A., Shindell, D., Winter, B., Bourqui, M., Faluvegi, G., Rozanov, E., Schraner, M., and Brönnimann, S.: Stratospheric winter climate response to ENSO in three chemistry-climate models, Geophys. Res. Lett., 35, L13819, doi:10.1029/2008GL034289, 2008.

Flury, T., Hocke, K., Haefele, A., Kämpfer, N., and Lehmann, R.: Ozone depletion, water vapor increase, and PSC generation at midlatitudes by the 2008 major stratospheric warming, J. Geophys. Res.-Atmos., 114, D18302, doi:10.1029/2009JD011940, 2009.

Gabriel, A., Körnich, H., Lossow, S., Peters, D. H. W., Urban, J., and Murtagh, D.: Zonal asymmetries in middle atmospheric ozone and water vapour derived from Odin satellite data 2001- 
2010, Atmos. Chem. Phys., 11, 9865-9885, doi:10.5194/acp-119865-2011, 2011a.

Gabriel, A., Schmidt, H., and Peters, D. H. W.: Effects of the 11 year solar cycle on middle atmospheric stationary wave patterns in temperature, ozone, and water vapor, J. Geophys. Res.-Atmos., 116, D23301, doi:10.1029/2011JD015825, 2011b.

Garcia, R. R., Dunkerton, T. J., Lieberman, R. S., and Vincent, R. A.: Climatology of the semiannual oscillation of the tropical middle atmosphere, J. Geophys. Res.-Atmos., 102, 2601926032, doi:10.1029/97JD00207, 1997.

Garfinkel, C. I., Silverman, V., Harnik, N., Haspel, C., and Riz, Y.: Stratospheric response to intraseasonal changes in incoming solar radiation, J. Geophys. Res.-Atmos., 120, 7648-7660, doi:10.1002/2015JD023244, 2015.

Gray, L. J., Beer, J., Geller, M., Haigh, J. D., Lockwood, M., Matthes, K., Cubasch, U., Fleitmann, D., Harrison, G., Hood, L., Luterbacher, J., Meehl, G. A., Shindell, D., van Geel, B., and White, W: Solar influences on climate, Rev. Geophys., 48, 20112031, 2010.

Greer, K., Thayer, J., and Harvey, V.: A climatology of polar winter stratopause warmings and associated planetary wave breaking, J. Geophys. Res.-Atmos., 118, 4168-4180, 2013.

Hocke, K., Studer, S., Martius, O., Scheiben, D., and Kämpfer, N.: A 20-day period standing oscillation in the northern winter stratosphere, Ann. Geophys., 31, 755-764, doi:10.5194/angeo31-755-2013, 2013.

Hollandsworth, S. M., Bowman, K. P., and McPeters, R. D.: Observational study of the quasi-biennial oscillation in ozone, J. Geophys. Res.-Atmos., 100, 7347-7361, doi:10.1029/95JD00193, 1995.

Hood, L., Soukharev, B., and McCormack, J.: Decadal variability of the tropical stratosphere: Secondary influence of the El NiñoSouthern Oscillation, J. Geophys. Res.-Atmos., 115, D11113, doi:10.1029/2009JD012291, 2010.

Hood, L. L. and McCormack, J. P.: Components of interannual ozone change based on Nimbus 7 TOMS data, Geophys. Res. Lett., 19, 2309-2312, 1992.

Huang, F. T., Mayr, H. G., Reber, C. A., Russell, J. M., Mlynczak, M. G., and Mengel, J. G.: Ozone quasi-biennial oscillations (QBO), semiannual oscillations (SAO), and correlations with temperature in the mesosphere, lower thermosphere, and stratosphere, based on measurements from SABER on TIMED and MLS on UARS, J. Geophys. Res. Space, 113, A01316, doi:10.1029/2007JA012634, 2008.

Ineson, S. and Scaife, A.: The role of the stratosphere in the European climate response to El Niño, Nat. Geosci.e, 2, 32-36, 2009.

Keckhut, P., Hauchecorne, A., Blanot, L., Hocke, K., GodinBeekmann, S., Bertaux, J.-L., Barrot, G., Kyrölä, E., van Gijsel, J. A. E., and Pazmino, A.: Mid-latitude ozone monitoring with the GOMOS-ENVISAT experiment version 5: the noise issue, Atmos. Chem. Phys., 10, 11839-11849, doi:10.5194/acp10-11839-2010, 2010.

Kodera, K. and Kuroda, Y.: Dynamical response to the solar cycle, J. Geophys. Res.-Atmos., 107, ACL 5-1-ACL 5-12, doi:10.1029/2002JD002224, 2002.

Kyrölä E., Tamminen, J., Sofieva, V., Bertaux, J. L., Hauchecorne, A., Dalaudier, F., Fussen, D., Vanhellemont, F., Fanton d'Andon, O., Barrot, G., Guirlet, M., Fehr, T., and Saavedra de Miguel, L.: GOMOS $\mathrm{O}_{3}, \mathrm{NO}_{2}$, and $\mathrm{NO}_{3}$ observations in 2002-2008,
Atmos. Chem. Phys., 10, 7723-7738, doi:10.5194/acp-10-77232010, 2010.

Leblanc, T. and McDermid, I. S.: Quasi-biennial oscillation signatures in ozone and temperature observed by lidar at Mauna Loa, Hawaii (19.5 $\left.{ }^{\circ} \mathrm{N}, 155.6^{\circ} \mathrm{W}\right)$, J. Geophys. Res.-Atmos., 106, 14869-14874, doi:10.1029/2001JD900162, 2001.

Lee, H. and Smith, A.: Simulation of the combined effects of solar cycle, quasi-biennial oscillation, and volcanic forcing on stratospheric ozone changes in recent decades, J. Geophys. Res.Atmos., 108, D2, doi:10.1029/2001JD001503, 2003.

Maeda, K.: Semiannual oscillation of stratospheric ozone, Geophys. Res. Lett., 11, 583-586, 1984.

Manzini, E.: Atmospheric science: ENSO and the stratosphere, Nat. Geosci., 2, 749-750, 2009.

Mitchell, D. M., Gray, L. J., Fujiwara, M., Hibino, T., Anstey, J. A., Ebisuzaki, W., Harada, Y., Long, C., Misios, S., Stott, P. A., and Tan, D.: Signatures of naturally induced variability in the atmosphere using multiple reanalysis datasets, Q. J. Roy. Meteor. Soc., 141, 2011-2031, doi:10.1002/qj.2492, 2014.

Moreira, L., Hocke, K., Eckert, E., von Clarmann, T., and Kämpfer, N.: Trend analysis of the 20-year time series of stratospheric ozone profiles observed by the GROMOS microwave radiometer at Bern, Atmos. Chem. Phys., 15, 10999-11009, doi:10.5194/acp-15-10999-2015, 2015.

Nair, P. J., Godin-Beekmann, S., Kuttippurath, J., Ancellet, G., Goutail, F., Pazmiño, A., Froidevaux, L., Zawodny, J. M., Evans, R. D., Wang, H. J., Anderson, J., and Pastel, M.: Ozone trends derived from the total column and vertical profiles at a northern mid-latitude station, Atmos. Chem. Phys., 13, 10373-10384, doi:10.5194/acp-13-10373-2013, 2013.

Navas-Guzmán, F., Stähli, O., and Kämpfer, N.: An integrated approach toward the incorporation of clouds in the temperature retrievals from microwave measurements, Atmos. Meas. Tech., 7, 1619-1628, doi:10.5194/amt-7-1619-2014, 2014.

Navas-Guzmán, F., Kämpfer, N., Murk, A., Larsson, R., Buehler, S. A., and Eriksson, P.: Zeeman effect in atmospheric $\mathrm{O}_{2}$ measured by ground-based microwave radiometry, Atmos. Meas. Tech., 8 , 1863-1874, doi:10.5194/amt-8-1863-2015, 2015.

Offermann, D., Goussev, O., Kalicinsky, C., Koppmann, R., Matthes, K., Schmidt, H., Steinbrecht, W., and Wintel, J.: A case study of multi-annual temperature oscillations in the atmosphere: Middle Europe, J. Atmos. Sol.-Terr. Phys., 135, 1-11, doi:10.1016/j.jastp.2015.10.003, 2015.

Perliski, L. M., Solomon, S., and London, J.: On the interpretation of seasonal variations of stratospheric ozone, Planet. Space Sci., 37, 1527-1538, doi:10.1016/0032-0633(89)90143-8, 1989.

Peter, R.: The ground-based millimeter-wave ozone spectrometerGROMOS, IAP Research Report, University of Bern, Bern, Switzerland, 1997.

Peter, R. and Kämpfer, N.: Short-term variations of mid-latitude ozone profiles during the winter 1994/95, in: Proc. Third Europ. Symp. on Polar $\mathrm{O}_{3}$ Res, 484-487, 1995.

Peter, R., Calisesi, Y., and Kämpfer, N.: Variability of middle atmospheric ozone abundances derived from continuous groundbased millimeter wave measurements, P., Soc. Photo.-Opt. Ins., 2, 559-562, 1996.

Randel, W. J. and Wu, F.: A stratospheric ozone profile data set for 1979-2005: Variability, trends, and comparisons with 
column ozone data, J. Geophys. Res.-Atmos., 112, D06313, doi:10.1029/2006JD007339, 2007.

Randel, W. J., Garcia, R. R., Calvo, N., and Marsh, D.: ENSO influence on zonal mean temperature and ozone in the tropical lower stratosphere, Geophys. Res. Lett., 36, L15822, doi:10.1029/2009GL039343, 2009.

Ray, E. A., Holton, J. R., Fishbein, E. F., Froidevaux, L., and Waters, J. W.: The Tropical Semiannual Oscillations in Temperature and Ozone as Observed by the MLS, J. Atmos. Sci., 51, 3045-3052, doi:10.1175/15200469(1994)051<3045:TTSOIT>2.0.CO;2, 1994.

Sassi, F., Kinnison, D., Boville, B., Garcia, R., and Roble, R.: Effect of El Niño-Southern Oscillation on the dynamical, thermal, and chemical structure of the middle atmosphere, J. Geophys. Res.Atmos., 109, D17108, doi:10.1029/2003JD004434, 2004.

Schanz, A., Hocke, K., and Kämpfer, N.: Daily ozone cycle in the stratosphere: global, regional and seasonal behaviour modelled with the Whole Atmosphere Community Climate Model, Atmos. Chem. Phys., 14, 7645-7663, doi:10.5194/acp-14-76452014, 2014.

Schneider, N., Selsis, F., Urban, J., Lezeaux, O., Noë, J., and Ricaud, P.: Seasonal and Diurnal Ozone Variations: Observations and Modeling, J. Atmos. Chem., 50, 25-47, doi:10.1007/s10874005-1172-z, 2005.

Stähli, O., Murk, A., Kämpfer, N., Mätzler, C., and Eriksson, P.: Microwave radiometer to retrieve temperature profiles from the surface to the stratopause, Atmos. Meas. Tech., 6, 2477-2494, doi:10.5194/amt-6-2477-2013, 2013.

Steinbrecht, W., Claude, H., and Winkler, P.: Enhanced upper stratospheric ozone: Sign of recovery or solar cycle effect?, J. Geophys. Res.-Atmos., 109, d02308, doi:10.1029/2003JD004284, 2004.

Steinbrecht, W., Claude, H., Schönenborn, F., McDermid, I. S., Leblanc, T., Godin, S., Song, T., Swart, D. P. J., Meijer, Y. J., Bodeker, G. E., Connor, B. J., Kämpfer, N., Hocke, K., Calisesi, Y., Schneider, N., de la Noë, J., Parrish, A. D., Boyd, I. S., Brühl, C., Steil, B., Giorgetta, M. A., Manzini, E., Thomason, L. W., Zawodny, J. M., McCormick, M. P., Russell, J. M., Bhartia, P. K., Stolarski, R. S., and Hollandsworth-Frith, S. M.: Long-term evolution of upper stratospheric ozone at selected stations of the Network for the Detection of Stratospheric Change (NDSC), J. Geophys. Res.-Atmos., 111, D10308, doi:10.1029/2005JD006454, 2006.

Steinbrecht, W., Claude, H., Schönenborn, F., McDermid, I. S., Leblanc, T., Godin-Beekmann, S., Keckhut, P., Hauchecorne, A., Gijsel, J. A. E. V., Swart, D. P. J., Bodeker, G. E., Parrish, A., Boyd, I. S., Kämpfer, N., Hocke, K., Stolarski, R. S., Frith, S. M., Thomason, L. W., Remsberg, E. E., Savigny, C. V., Rozanov, A., and Burrows, J. P.: Ozone and temperature trends in the upper stratosphere at five stations of the Network for the Detection of Atmospheric Composition Change, Int. J. Remote Sens., 30, 3875-3886, 2009.
Stiller, G. P., von Clarmann, T., Haenel, F., Funke, B., Glatthor, N., Grabowski, U., Kellmann, S., Kiefer, M., Linden, A., Lossow, S., and López-Puertas, M.: Observed temporal evolution of global mean age of stratospheric air for the 2002 to 2010 period, Atmos. Chem. Phys., 12, 3311-3331, doi:10.5194/acp-12-33112012, 2012.

Studer, S., Hocke, K., and Kämpfer, N.: Intraseasonal oscillations of stratospheric ozone above Switzerland, J. Atmos. Sol.-Terr. Phys., 74, 189-198, doi:10.1016/j.jastp.2011.10.020, 2012.

Studer, S., Hocke, K., Pastel, M., Godin-Beekmann, S., and Kämpfer, N.: Intercomparison of stratospheric ozone profiles for the assessment of the upgraded GROMOS radiometer at Bern, Atmos. Meas. Tech. Discuss., 6, 6097-6146, doi:10.5194/amtd6-6097-2013, 2013.

Studer, S., Hocke, K., Schanz, A., Schmidt, H., and Kämpfer, N.: A climatology of the diurnal variations in stratospheric and mesospheric ozone over Bern, Switzerland, Atmos. Chem. Phys., 14, 5905-5919, doi:10.5194/acp-14-5905-2014, 2014.

van Gijsel, J. A. E., Swart, D. P. J., Baray, J.-L., Bencherif, H., Claude, H., Fehr, T., Godin-Beekmann, S., Hansen, G. H., Keckhut, P., Leblanc, T., McDermid, I. S., Meijer, Y. J., Nakane, H., Quel, E. J., Stebel, K., Steinbrecht, W., Strawbridge, K. B., Tatarov, B. I., and Wolfram, E. A.: GOMOS ozone profile validation using ground-based and balloon sonde measurements, Atmos. Chem. Phys., 10, 10473-10488, doi:10.5194/acp10-10473-2010, 2010.

van Loon, H. and Labitzke, K.: The Southern Oscillation. Part V: The Anomalies in the Lower Stratosphere of the Northern Hemisphere in Winter and a Comparison with the Quasi-Biennial Oscillation, Mon. Weather Rev., 115, 357-369, doi:10.1175/15200493(1987)115<0357:TSOPVT>2.0.CO;2, 1987.

Van Loon, H. and Labitzke, K.: The influence of the 11-year solar cycle on the stratosphere below $30 \mathrm{~km}$ : A review, Space Sci. Rev., 94, 259-278, 2000.

von Clarmann, T., Stiller, G., Grabowski, U., Eckert, E., and Orphal, J.: Technical Note: Trend estimation from irregularly sampled, correlated data, Atmos. Chem. Phys., 10, 6737-6747, doi:10.5194/acp-10-6737-2010, 2010.

White, W. B. and Liu, Z.: Non-linear alignment of El Niño to the 11-yr solar cycle, Geophys. Res. Lett., 35, L19607, doi:10.1029/2008GL034831, 2008.

WMO: Scientific Assessment of Ozone Depletion: 2010, Global Ozone Research and Monitoring Project-Report No.52, Geneva, Switzerland, 516 pp., 2011.

WMO: Scientific Assessment of Ozone Depletion: 2014, Global Ozone Research and Monitoring Project-Report No.55, Geneva, Switzerland, 416 pp., 2014.

Yang, E.-S., Cunnold, D. M., Salawitch, R. J., McCormick, M. P., Russell, J., Zawodny, J. M., Oltmans, S., and Newchurch, M. J.: Attribution of recovery in lower-stratospheric ozone, J. Geophys. Res.-Atmos., 111, D17309, doi:10.1029/2005JD006371, 2006. 